\title{
Surgical management of tuboovarian abscess: Results of retrospective case series
}

\author{
Tubaovaryan apsenin cerrahi yönetimi: Olgu serilerinin retrospektif sonuçları
}

\author{
Hüseyin Cengiz, Hediye Dağdeviren, Murat Ekin, Cihan Kaya, Şükrü Yıldız, Levent Yaşar
}

\section{ABSTRACT}

Objectives: Tuboovarian abscess (TOA) is a serious and potentially life-threatening condition. Treatment modalities vary as broad spectrum of antibiotherapy, minimallyinvasive drainage procedures, invasive surgery or combinations of these interventions. The objective of this study was to evaluate surgically treated patients for TOA.

Materials and methods: The medical records of 57 cases who had surgically treated for TOA at Bakirkoy Dr. Sadi Konuk Education and Research Hospital, Department of Obstetrics and Gynecology from January 2007 to September 2012 were evaluated retrospectively.

Results: The average age was 37.2 years and the mean gravidity and parity were 2.9 and 2.1 , respectively. The most common presenting symptom was abdominal pain $47.4 \%(n=27)$. Twenty eight $(49.1 \%)$ of the patients had laparotomy and twenty nine $(50.9 \%)$ of the patients had laparoscopic surgery. 6 patients had a ruptured TOA and $17.9 \%$ of the patients had complications.

Conclusions: The choice of an open or laparoscopic surgical approach should be largely based on operator skill, experience, and ability to perform the necessary surgical maneuvers. J Clin Exp Invest 2012; 3(4): 463-466

Key words: Complication, laparoscopy, surgery, tuboovarian abscess

\section{INTRODUCTION}

A tuboovarian abscess (TOA) is an inflammatory mass involving the fallopian tube, ovary and other adjacent pelvic organs (eg, bowel, bladder) occasionally. ${ }^{1}$ These abscesses are seen most commonly in reproductive age women and typically originated from upper genital tract infection. TOA is a complication of pelvic inflammatory disease (PID) in $15 \%$ of cases, and $33 \%$ of patients requiring admission with PID, have a TOA. ${ }^{2}$ TOA's are polymicrobial infections and E.coli, B.fragilis, peptococci, peptostreptococci and mix flora especially encountered microorganisms in abscess cavity. The pathogen-

\section{ÖZET}

Amaç: Tubaovaryan apse (TOA) ciddi ve hayati tehlikesi bulunan bir durumdur. Tedavi şekilleri olarak geniş spektrumlu antibioterapi, minimal invaziv abse drenajı, invaziv cerrahi veya bu tedavi usullerinin kombinasyonunu içermektedir. Bu çalışmanın amacı cerrahi olarak tedavi edilmiş TOA olgularını değerlendirmektir.

Gereç ve yöntem: Ocak 2007-Eylül 2012 tarihleri arasında Bakırköy Dr. Sadi Konuk Eğitim ve Araştırma Hastanesi Kadın Hastalıkları ve Doğum kliniğinde yatırılıp cerrahi tedavisi yapılan hastalar retrospektif olarak incelendi.

Bulgular: TOA olgularında ortalama yaş 37.2 olarak saptandı. Ortalama gravida ve parite sırası ile 2.9 ve 2.1 olarak bulundu. En sık saptanan semptom olarak \%47.4 $(n=27)$ oranı ile karın ağrısı izlendi. \%49.1 $(n=28)$ hasta laparatomik cerrahi ve \%50.9 $(n=29)$ hasta laparaskopik cerrahi geçirdi. 6 hastada rüptüre TOA izlendi ve \%17.9 hastada komplikasyon gelişti.

Sonuç: Gerekli cerrahi müdahaleleri gerçekleştirmek için, açık veya laparoskopik cerrahi yaklaşımın seçimi büyük ölçüde operatörün beceri, deneyim ve yeteneğine bağlıdır.

Anahtar kelimeler: Cerrahi, Komplikasyon, laparoskopi, tubaovaryan apse

esis of TOA is due to fallopian tubal necrosis and epithelial damage by bacterial pathogens causing a favorable environment for anaerobic invasion and growth. Also these abscesses have important risk factors. Some of these risk factors are IUD use, age $>40$, adoloscence, low socioeconomic status, multiple sex partners and nulliparity. The most important risk factor in tuba ovarian abscess formation is intercourse a partner having infection because of this disease caused by sexually transmitted infections. Malignancies, gynecological surgery, in vitro fertilization, perforated appendicitis and diverticulitis have also shown to cause abscess formation in lit-

Bakırköy Dr. Sadi Konuk Education and Research Hospital, Obstetrics and Gynecology istanbul, Turkey

Correspondence: Hüseyin Cengiz,

Bakırköy Dr. Sadi Konuk Education and Research Hospital Obstetrics and Gynecology İstanbul Email: obstetrik@gmail.com

Received: 11.10.2012, Accepted: 30.11.2012

Copyright (C) JCEI / Journal of Clinical and Experimental Investigations 2012, All rights reserved 
erature. Also it is rarely seen in virgins. In literatue a few cases were published about TOA in virgin patients. ${ }^{3}$ TOA's especially result in irreversible tubal and ovarian damage and this is a potential threat to fertility. Also this disease may be accompanied other complications such as incapacitating abdominal pain, ectopic pregnancy and abscess rupture. Aggressive medical and/or surgical therapy is required and rupture of an abscess may result in sepsis. ${ }^{4,5}$ Mortality associated with TOA has decreased dramatically over the last 50 years, however the route of management varies. Treatment modalities include broad spectrum antibiotherapy, minimallyinvasive drainage procedures, invasive surgery, or combinations of these interventions.

The objective of this study was to evaluate surgically treated patients for TOA.

\section{MATERIALS AND METHODS}

The medical records of the patients who had surgically treated for TOA at Bakirkoy Dr. Sadi Konuk Education and Research Hospital, Department of Obstetrics and Gynecology from January 2007 to September 2012 were evaluated retrospectively. Patients were preoperatively diagnosed as TOA relying on laboratory and ultrasonographic findings in the presence of a mass at the pelvic examination. Ultrasonographic images of TOAs were complex multilocular masses that often obliterate the normal adnexal architecture and/or cul-de-sac anatomy, speckled fluid and internal echoes consistent with inflammatory debris.6-8 Complications were defined as factors that could result in prolonged hospitalization as; intensive care unit (ICU) admission, bowel or bladder injury, blood transfusion, blood loss $>1000 \mathrm{~mL}$, sepsis or bacteremia, ileus, conversion from laparoscopy to laparotomy, and death. Fever was defined as a temperature greater than $38^{\circ} \mathrm{C}$.

In our series, antibiotics were started all the patients at the admission to the hospital. After 48 to 72 hours of treatment with antibiotics alone, patients who do not respond to the medical therapy or who had a worsen vital findings, required either minimally invasive abscess drainage or surgery. Statistical Analysis was performed by using the SPSS 20.0 Statistical Software Package (SPSS, Chicago, IL, USA).

\section{RESULTS}

57 patients with preoperative diagnosis of TOA were undergone for surgical treatment. The average age was 37.2 years and the mean gravidity and parity were 2.9 and 2.1 , respectively. $21.1 \%$ of the cases had a history of PID and $17.5 \%$ of the patients had smoking habit. The most common symptom was abdominal pain $47.4 \%(n=27) .29 .8 \%(n=17)$ of the cases had fever during admission. $49.1 \%(n=28)$ of the patients had laparotomy and $\% 50.9(n=29)$ had laparoscopic surgery. 6 patients had a ruptured TOA and $17.9 \%$ of the patients had complications. Clinical characteristics of the study population are noted in Table 1.

Table 1. Clinical characteristics of the patients with tubo-ovarian abscess

\begin{tabular}{|c|c|c|c|c|c|c|}
\hline & Mean $\pm \mathrm{SD} / \mathrm{n}$ & $\%$ & & & Mean $\pm S D / n$ & $\%$ \\
\hline Age & $37,2 \pm 9,1$ & & $\mathrm{WBC}, / \mathrm{mm}^{3}$ & & $14254 \pm 4554$ & \\
\hline Gravidity & $2,9 \pm 1,7$ & & & $<10000$ & 13 & $22,8 \%$ \\
\hline Parity & $2,1 \pm 1,2$ & & WBC & 10000 to 15000 & 19 & $33,3 \%$ \\
\hline Smoking & 10 & $17,5 \%$ & & $>15000$ & 25 & $43,9 \%$ \\
\hline Previous PID & 12 & $21,1 \%$ & Abscess location & Right & 15 & $26,3 \%$ \\
\hline Contraception & 21 & $36,8 \%$ & & Left & 29 & $50,9 \%$ \\
\hline Pain & 27 & $47,4 \%$ & & Bilateral & 13 & $22,8 \%$ \\
\hline Abnormal uterine bleeding & 12 & $21,1 \%$ & Abscess size & $0-4 \mathrm{~cm}$ & 15 & $26,3 \%$ \\
\hline Abnormal discharge & 17 & $29,8 \%$ & & $5-8 \mathrm{~cm}$ & 28 & $49,1 \%$ \\
\hline Fever & 17 & $29,8 \%$ & & $>8 \mathrm{~cm}$ & 14 & $24,6 \%$ \\
\hline Rebound & 18 & $31,6 \%$ & Febrile days & 0 & 44 & $77,2 \%$ \\
\hline Guarding & 19 & $33,3 \%$ & & 1 & 4 & $7,0 \%$ \\
\hline Uterine tenderness & 24 & $42,1 \%$ & & 2 & 8 & $14,0 \%$ \\
\hline Adnexal tenderness & 24 & $42,1 \%$ & & 3 & 1 & $1,8 \%$ \\
\hline Cervical motion tenderness & 21 & $36,8 \%$ & Complication & & 10 & $17,9 \%$ \\
\hline Treatment laparatomy & 28 & $49,1 \%$ & Rupture & & 6 & $10,5 \%$ \\
\hline Treatment laparoscopy & 29 & $50,9 \%$ & Hospitalization (Days) & & $6,3 \pm 3,8$ & \\
\hline
\end{tabular}

PID, Pelvic inflammatory disease; WBC, White blood cells, SD= standard deviation 
Table 2. Comparison of some variables according to existence of fever in tubo-ovarian abscess patients

\begin{tabular}{|c|c|c|c|c|c|c|}
\hline & & \multicolumn{4}{|c|}{ Febrile } & \multirow{3}{*}{$p$} \\
\hline & & \multicolumn{2}{|c|}{ Negative } & \multicolumn{2}{|c|}{ Positive } & \\
\hline & & Mean $\pm S D / n$ & $\%$ & Mean $\pm S D / n$ & $\%$ & \\
\hline WBC & & $13250 \pm 4157$ & & $17650 \pm 4318$ & & 0,002 \\
\hline \multirow[t]{3}{*}{ WBC } & $<10000$ & 13 & $29,5 \%$ & 0 & $0,0 \%$ & 0,075 \\
\hline & 10000 to 15000 & 14 & $31,8 \%$ & 5 & $38,5 \%$ & \\
\hline & $>15000$ & 17 & $38,6 \%$ & 8 & $61,5 \%$ & \\
\hline \multirow[t]{2}{*}{ Complication } & Negative & 36 & $83,7 \%$ & 10 & $76,9 \%$ & 0,575 \\
\hline & Positive & 7 & $16,3 \%$ & 3 & $23,1 \%$ & \\
\hline Hospitalization (Days) & & $6,5 \pm 4,1$ & & $5,5 \pm 2,3$ & & 0,075 \\
\hline
\end{tabular}

Chi-square test / I.S t test, WBC, White blood cells, SD= standard deviation

\section{DISCUSSION}

Tuboovarian abscesses are usually found among reproductive age women. Abdominal pain, vaginal discharge and fever are usually seen in TOA patients. ${ }^{9}$ In our series, we found abdominal pain as the most common presenting symptom. Ginsburg et $\mathrm{al}^{10}$ reported previous PID in TOA patients as $\% 49$. Our patients had a $21.1 \%$ previous PID rate. Diagnosing and managing adnexal masses can be problematic for physicians. A preoperative disease classification for patients with adnexal masses, in particular discrimination between benign and malignant ovarian tumors, is important for optimal patient management. ${ }^{11}$ It is unclear whether a subjective evaluation of a US image (i.e., pattern recognition) of an adnexal mass. In one study the sensitivity of ultrasonography in the diagnosis of TOA was found as $93 \%$, while specificity was $98.6 \% .{ }^{12}$ In our daily practice we also use ultrasonography as a major diagnostic tool.

Medical management with broad spectrum antibiotics is now generally considered as the initial management for unruptured Tubaovarian abscess. ${ }^{13}$ TOA's are polymicrobial infections and E.coli, B.fragilis, peptococci, peptostreptococci, A. israeli and mix flora especially encountered microorganisms in abscess cavity. The 2010 Center for Disease Control and Prevention Sexually Transmitted Diseases Treatment Guidelines recommends inpatient intravenous antibiotics for at least 24 hours. No specific inpatient antibiotic regimen is suggested. Upon discontinuation of parenteral therapy, the CDC recommends that clindamycin or metronidazole be used with doxycycline for a total of 14 days of treatment. Treatment of TOA was thought to require bilateral oophorectomy and hysterectomy. However, optimal treatment of TOA remains unclear. Doganay $\mathrm{M}$. et $\mathrm{al}^{14}$ aimed to find out the optimal therapau- tic approach in patients. They were used a scoring system for defining the beneficial treatment modality. According to their study laparascopy seems to be the optimal treatment modality and medical treatment may be a reasonable alternative in well selected cases since it does not carry a risk of operative complications. Surgery or drainage should be considered when the patient displays a failure to respond to therapy in 48 to 72 hours. ${ }^{15}$ In our clinic, we use the same algorithm for TOA. Today, the preferable management options are minimally invasive technics with conservative approach. In many clinics laparoscopy has been the gold standard for the diagnosis and treatment of TOA. Henry-Suchet et al carried out laparoscopic adhesiolysis and drainage of abscess in combination with antibiotics in 50 women. ${ }^{16}$ In 45 patients (90\%) the approach was successful, while five patients $(10 \%)$ required further surgery. Reich et al reported no complications following laparoscopic and organ-preserving management of tubo-ovarian abscess in 25 patients. ${ }^{17}$ Raiga et al also demonstrated that operative laparoscopy involving drainage of adnexal abscesses is a safe and effective procedure..$^{18}$ In our study, 29 patients treated laparoscopically. Buchweitz et al reported no complications in the patients who underwent laparoscopic organ-preserving treatment. ${ }^{19}$ We defined conversion from laparoscopy to laparotomy as a complication and we evaluate these cases within the laparotomy group. 10 patients had complications in our study but 7 of them were laparoscopy to laparatomy conversion. There were two bowel injuries in 28 patients undergoing laparatomy. Only one port side infection occurred with laparoscopy in 29 patients undergoing laparoscopy. The limitations of our study include a relatively small number of TOAs

In conclusion, the choice of an open or laparoscopic surgical approach should be largely based 
on operator skill, experience, and ability to perform the necessary surgical maneuvers given the anatomical distortion.

\section{REFERENCES}

1. Granberg S, Gjelland K, Ekerhovd E. The management of pelvic abscess. Best Pract Res Clin Obstet Gynaecol 2009;23(5):667.

2. D. V. L anders and R. L. Sweet, "Tubo-ovarian abscess: contemporary approach to management," Reviews of Infectious Diseases, vol. 5, no. 5, pp. 876-884, 1983.

3. Tuncer SZ, Boyraz G, Yücel SÖ, Selçuk I, Yazıcıoglu A. Tuboovarian abscess due to colonic diverticulitis in a virgin patient with morbid obesity: A case report. Case Report Med 2012;2012: 413185

4. Pedowitz P, Bloomfield Rd. Ruptured adnexal abscess (tuboovarian) with generalized peritonitis. Am J Obstet Gynecol 1964;88: 721.

5. Vermeeren J, Te Linde Rw. Intraabdominal rupture of pelvic abscesses. Am J Obstet Gynecol 1954; 68(1):402.

6. Landers DV, Sweet RL. Tubo-ovarian abscess: contemporary approach to management. Rev Infect Dis 1983;5(5):876.

7. Wiesenfeld HC, Sweet RL. Progress in the management of tuboovarian abscesses. Clin Obstet Gynecol 1993;36(2):433.

8. Gagliardi PD, Hoffer PB, Rosenfield AT. Correlative imaging in abdominal infection: an algorithmic approach using nuclear medicine, ultrasound, and computed tomography. Semin Nucl Med 1988;18(4):320.

9. Martens MG. Pelvic inflammatory Disease. In: Rock JA, Jones HW, editors. $9^{\text {th }}$ ed. TeLindes Operative Gynecology 2003. P. 675-704.
10. Ginsburg DS, Stern JL, Hamod KA, Genadry R, Spence MR. Tubo-ovarian abscess: a retrospective review. Am J Obstet Gynecol 1980;138:10558.

11. Yildiz P, Cengiz H, Yildiz G, Sam DA, Yavuzcan A, Celikbas B, Sahin L. Two Unusual Clinical Presentations of Broad Ligament Leimyomas: A Report of Two Cases. Medicina (Kaunas) 2012;48(3):163-5.

12. Taylor KJ, Wasson JF, De Graaff $C$ et al. Accuracy of grey-scale ultrasound diagnosis of abdominal and pelvic abscesses in 220 patients. Lancet 1978;1:8384.

13. R. L. Sweet, "Tubo-ovarian abscess," in Pelvic Inflammatory Disease, pp. 101-124, Taylor \& Francis, London, UK, 2006.

14. Doganay M, Iskender C, Kilic S, Karayalcin R, Moralioglu O, Mollamahmutoglu L. Treatment approaches in tubo-ovarian abscesses according to scoring system. Bratisl Lek Listy 2011;112(4):200-3.

15. L. A. McNutt, C. Wu, X. Xue, and J. P. Hafner, "Estimating the relative risk in cohort studies and clinical trials of common outcomes," Am J Epidemiol 2003;157(10):940-3.

16. Henry-Suchet J, Soler A \& Loffredo V. Laparoscopic treatment of tuboovarian abscesses. J Reprod Med 1984;29(8):579-82.

17. Reich H \& McGlynn F. Laparoscopic treatment of tuboovarian and pelvic abscess. J Reprod Med 1987;32(10):747-52.

18. Raiga J, Canis M, Le Boue" dec G et al. Laparoscopic management of adnexal abscesses: consequences for fertility. Fertil Steril 1996;66(5):712-7.

19. Buchweitz O, Malik E, Kressin P et al. Laparoscopic management of tubo-ovarian abscesses: retrospective analysis of 60 cases. Surg Endosc 2000;14(10):94850. 